\title{
Research of Rainwater Infiltration in Eastern Slovakia
}

\author{
Gabriela Hudáková ${ }^{1}$, Martina Zeleňáková ${ }^{1}$, Ladislav Tometz $^{2}$ \\ ${ }^{1}$ Technical University of Košice \\ Faculty of Civil Engineering, Institute of Environmental Engineering \\ e-mail: gabrielahudakovaa@gmail.com,martina.zelenakova@tuke.sk \\ ${ }^{2}$ Technical University of Košice \\ Faculty of Mining, Ecology, Process Control and Geotechnology, Institute of Geoscience \\ e-mail: gabrielahudakovaa@gmail.com, martina.zelenakova@tuke.sk
}

\begin{abstract}
Today precipitation water in the majority of built up and other sealed surface areas no longer reach the water circulation system via natural routes. This can lead to long-term changes to the soil and water resources, reduce the natural local regeneration of the groundwater and have effects on the chemical and biological conditions above and below the ground surface. Reasonable rainwater management leads to maintain or recover a sound and sustainable water cycle. The purpose of this paper is to present objectives and monitoring of a drainage project in Eastern Slovakia, in Kosice city. The paper focuses on percolation facilities in the research area of campus of Technical University and measurements connected with rainwater infiltration.
\end{abstract}

Key words: rainwater, infiltration, percolation, rain gauge, rainfall-drainage process, surface runoff

\section{Introduction}

The concept of drainage in cities, which aims to mitigate the impact of urbanization on the hydrological regime of the country and on aquatic ecosystems, comes from our experience and knowledge of current methods of sewerage. A new concept of capture and use of water from surface run-off provides a platform for new technical and non-technical measures, applicable to drainage on private property as well as the public part of the urban drainage area [1], [2].

Infiltration can occur naturally following precipitation, or can be induced artificially through structural modifications in the ground surface. Some water that infiltrates will remain in the soil layer, where it will gradually move vertically and horizontally through the soil and subsurface material. Eventually, it might enter a stream by seepage into the stream bank. Some of the water may continue to move deeper (percolate), recharging the local groundwater aquifer. Dry soil has a defined capacity for infiltrating water. The capacity can be expressed as the depth to which water can infiltrate per unit time, such as inches per hour or millimetre per second. If rainfall supplies water at a rate that is greater than the infiltration capacity, 
water will infiltrate at the capacity rate and the excess is either ponded, moved as surface runoff, or evaporated. If rainfall supplies water at a rate less than the infiltration capacity, all of the incoming water volume will infiltrate. In both cases, as water infiltrates into the soil, the capacity to infiltrate more water gradually decreases and approaches a minimum capacity. When the supply rate is equal to or greater than the capacity to infiltrate, the minimum capacity will be approached more quickly than when the supply rate is much less than the infiltration capacity.

The emerging goal of urban rainwater management is to achieve effective control of pollutants in rainwater runoff and reduce the volume and rate of runoff to control downstream impacts from flooding and stream-channel erosion [3]. Surface runoff in urbanized environment is essentially the same as in the natural environment. The process, however, differs substantially from the rainfall-runoff processes in a natural basin. The main reason for these differences is the change in permeability of the surface and modifications of runoff caused by urban runoff drainage [4].

It should be noted that the main parameter affecting the intensity of rainwater percolation process, and thereby the required geometry of the equipment and investment expenses, is the coefficient of soil filtration $k_{\mathrm{f}}$ - coefficient of hydraulic conductivity [5]. It characterizes the ability of soil to absorb and transmit the water through a particular type of soil, and its value depends mainly on the composition of soil, its particle size and porosity.

The aim of the article is compare the values of coefficient of hydraulic conductivity in the study area obtained by laboratory test and by calculation.

\section{Material and methods}

\subsection{Study areas}

The areas of interest are located in eastern Slovakia in two different regions, in the cities of Košice and Prešov (Figure 1).

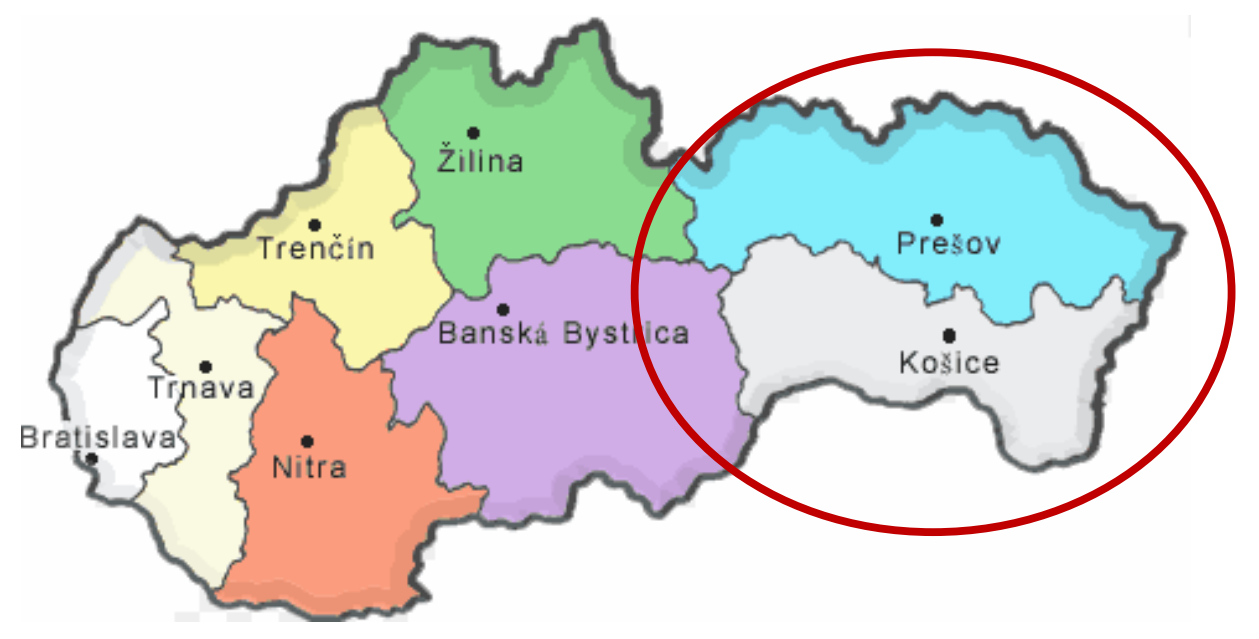

Figure 1: Study areas: Košice and Prešov 
There are two percolation shafts (A and B) in the campus of Technical University of Košice (Fig.2).

In the shaft A (Fig.3) is situated a universal data unit M4016. All devices, located in both shafts, are connected to this control unit. Under inflow of rainwater, respectively rain outlet pipe in the shafts, there are measurement flumes for metering of inflow rainwater from the roof of nearby building. Pressure sensor is placed at the bottom of shafts and are used for continuous measurements of the height of water levels in the shafts. The pressure sensor is connected with data communication cable to control unit M4016 where the measured data is sent to the server $[6,7,8]$.

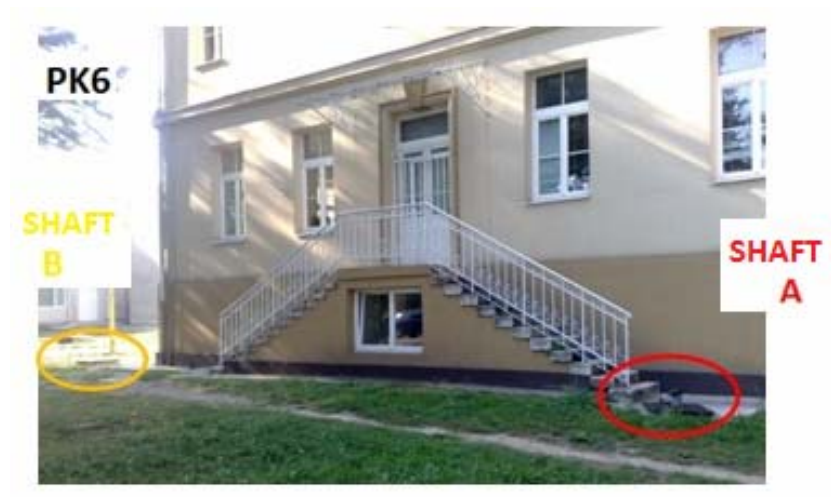

Figure 2: Infiltration shaft in Košice

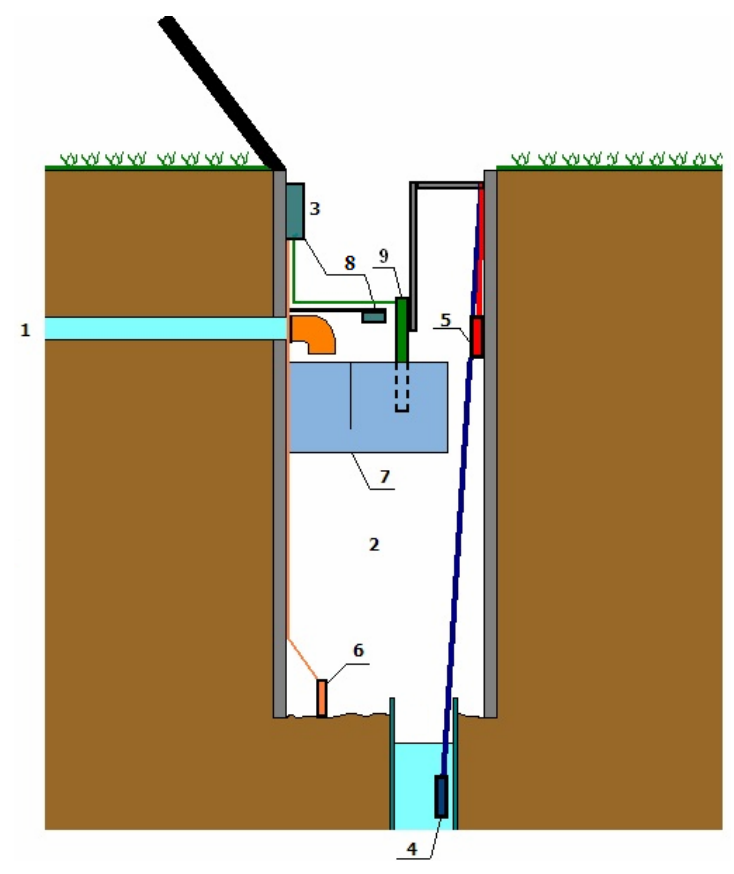

Figure 3: Infiltration shaft in Košice

1 - Supply of rainwater, 2 - Percolation shaft, 3 - Data telemetry unit M4016, 4 - levelogger 5 - barologger 6 pressure sensor, 7 - specific flow , 8 - Ultrasound sensor - flowmeter 9 - Multipurpose probe 
In Prešov is installed infiltration gallery in the locality Šarišske Lúky depicted in Fig.4, which contains similar instruments as in Košice. The samples of soil were taken from both localities and in the laboratory were determined the filtration coefficient for all the three samples.

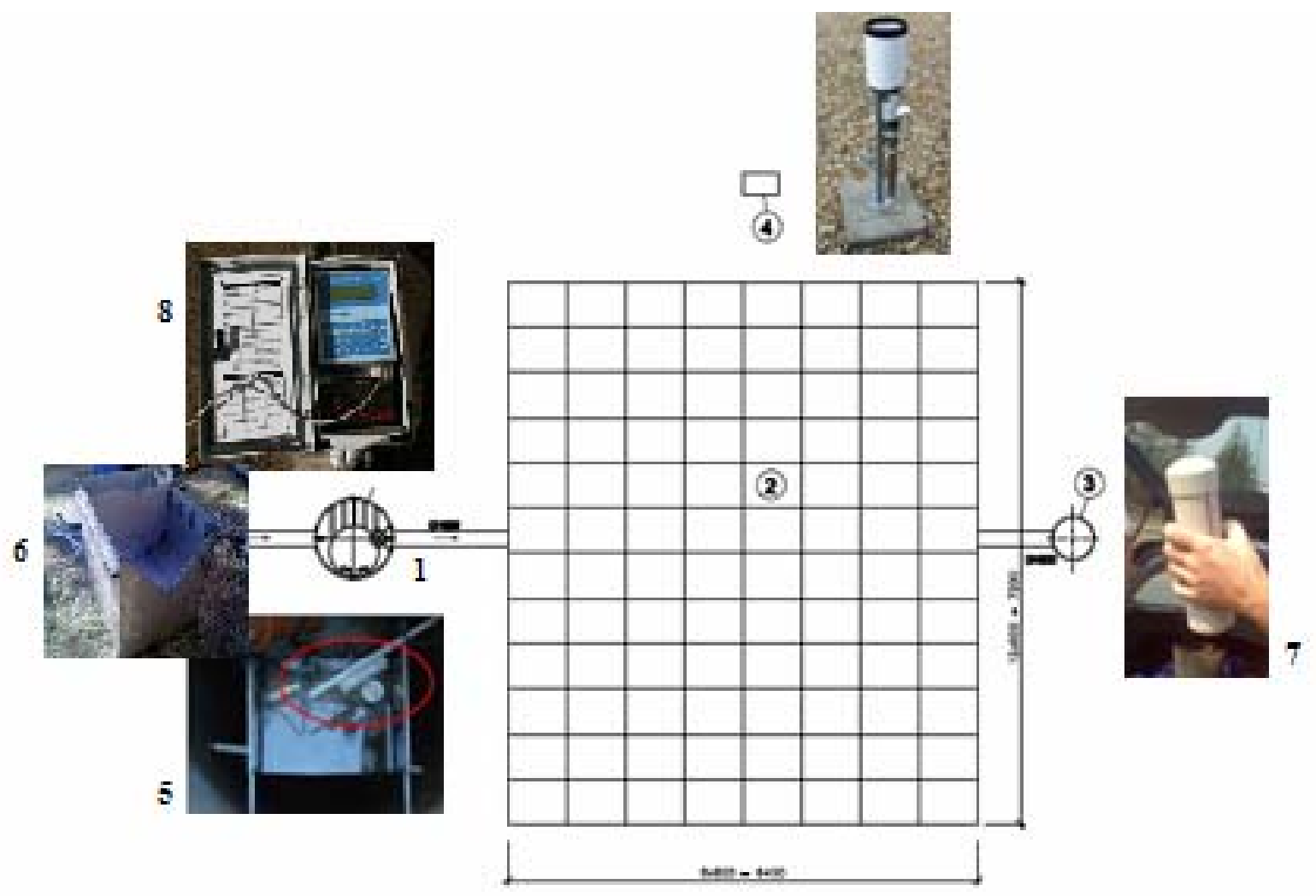

Fig. 4 Infiltration gallery in Prešov

1 - filter shaft, 2 - infiltration gallery, 3 - manholes, 4 - rain gauge, 5 - ultrasound sensor - flowmeter, 6 - specific flow, 7 - float, 8 - data telemetry unit M4016

The data from installed measuring devices were used in the numerical analysis - calculations of coefficients of filtration.

\subsection{Numerical analysis}

Filtration systems are highly dependent on local conditions, especially the permeability of the soil. The greatest importance is therefore the correct determination of the coefficient of filtration. Coefficient of hydraulic conductivity can be determined in several ways. The paper presents the calculation of the coefficient of filtration according to the standard CSN 759010.

$$
\begin{gathered}
Q_{P}=\frac{V}{t_{E}}\left[\mathrm{~m}^{3} \cdot \mathrm{s}^{-1}\right] \\
A_{P k}=\pi \cdot r^{2}\left[\mathrm{~m}^{2}\right] \\
A_{P p}=a . . b\left[\mathrm{~m}^{2}\right.
\end{gathered}
$$




$$
k_{f}=\frac{f_{R} \cdot Q_{P}}{A_{P}}\left[\mathrm{~m} \cdot \mathrm{s}^{-1}\right]
$$

where: $Q_{\mathrm{P}}-$ percolation rate $\left[\mathrm{m}^{3} \cdot \mathrm{s}^{-1}\right]$,

$t_{\mathrm{E}}-$ emptying time $[\mathrm{s}]$,

$V$ - storage volume $\left[\mathrm{m}^{3}\right]$,

$f_{\mathrm{R}}$ - surcharge factor $(f=2,0)$,

$k_{\mathrm{f}}-$ coefficient of hydraulic conductivity $\left[\mathrm{m} . \mathrm{s}^{-1}\right]$,

$A_{\text {Pk }}$ - percolation area in Košice $\left[\mathrm{m}^{2}\right]$,

$A_{\mathrm{Pp}}-$ percolation area in Prešov $\left[\mathrm{m}^{2}\right]$,

$\pi$ - ludolf number $(\pi=3,14)$,

$r$ - radius of infiltration shaft in Košice $(0.5 \mathrm{~m})$,

$a, b-$ sides of the infiltration gallery in Prešov.

$$
(a=8 \times 0.8=6.4 \mathrm{~m} ; b=12 \times 0.6=7.2 \mathrm{~m}) .
$$

The values which are necessary inputs for calculation are presented in Tables $1-3$ according to location Košice and Prešov.

\subsection{Laboratory analysis}

Samples from locations of our interest were carried off to the laboratory to determine the coefficient of hydraulic conductivity - coefficient of filtration. The process of determination of the curve of granularity in laboratories until the determination of the coefficient of filtration is shown in Fig. 5:

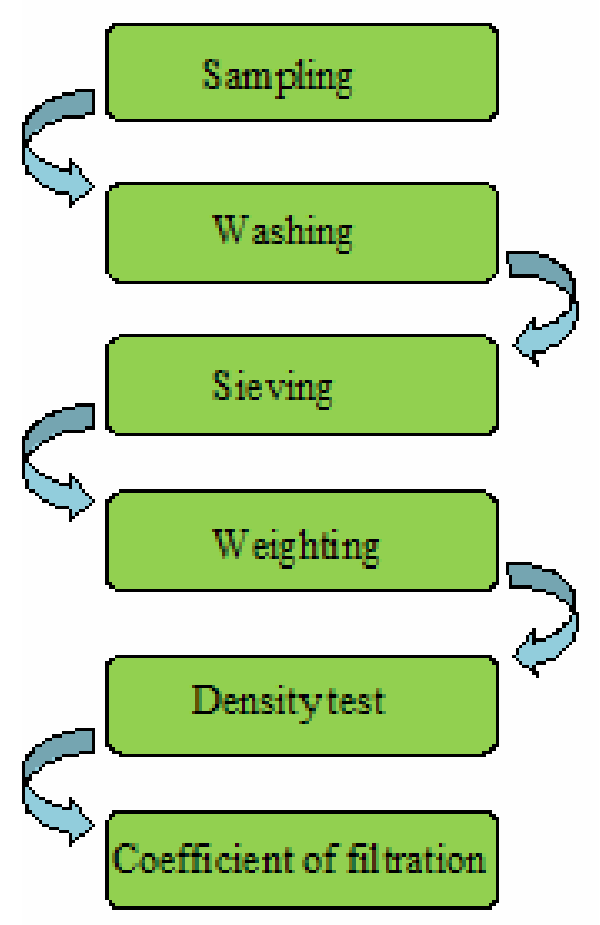

Figure 5: Procedure of laboratory analysis 
The procedure of the determination of soil's granularity followed by determination of the coefficient of filtration involves five steps mentioned in Fig. 5.

\section{Results}

The input data, which are necessary for the calculation of coefficient filtration in Košice (shaft A and B) and Prešov according to ČSN 75 9010, according to equations (1)-(4), are presented in Tab.1, 2 and Tab.3. The input data include storage volume - volume of rainwater in the shaft (gallery) which is necessary to infiltrate; time of infiltration - it is time from the finish of the rain (maximum volume in the infiltration facility) to time to emptying the infiltration facility. The percolation rate was calculating from (1), the percolation area in Košice was calculating from (2), the percolation area in Prešov was calculating from (3), and finally the coefficient of hydraulic conductivity $k_{\mathrm{f}}$ was calculating from (4).

The calculated coefficients of filtration, based on the input parameters are presented in Tab.13.

Table 1: Calculated coefficient of filtration in infiltration shaft A - Košice according to ČSN 759010

\begin{tabular}{|c|c|c|c|c|c|c|c|}
\hline Date & $\begin{array}{c}\text { Time } \\
\text { from }\end{array}$ & $\begin{array}{c}\text { Time } \\
\text { to }\end{array}$ & $\begin{array}{c}\text { Volume } \\
{\left[\mathbf{m}^{3}\right]}\end{array}$ & $\begin{array}{c}\text { Time } \\
{[\mathbf{s}]}\end{array}$ & $\begin{array}{c}\mathbf{Q}_{\mathbf{P}} \\
{\left[\mathbf{m}^{3} \cdot \mathbf{s}^{-1}\right]}\end{array}$ & $\begin{array}{c}\mathbf{A}_{\mathbf{P}} \\
{\left[\mathbf{m}^{2}\right]}\end{array}$ & $\begin{array}{c}\mathbf{k}_{\mathbf{f}} \\
{\left[\mathbf{m . s}^{-1}\right]}\end{array}$ \\
\hline $\begin{array}{c}5.11 .2013 \\
6.11 .2013\end{array}$ & $13: 36$ & $1: 00$ & 2.03 & 41040 & $4.95 .10^{-5}$ & 0.785 & $1.26 .10^{-4}$ \\
\hline $\begin{array}{c}9.11 .2013 \\
10.11 .2013\end{array}$ & $20: 02$ & $5: 08$ & 0.77 & 32760 & $2.35 .10^{-5}$ & 0.785 & $5.99 .10^{-5}$ \\
\hline 19.3 .2013 & $2: 03$ & $11: 18$ & 0.17 & 33300 & $5.11 .10^{-6}$ & 0.785 & $1.30 .10^{-5}$ \\
\hline $\begin{array}{c}14.1 .2013 \\
15.1 .2013\end{array}$ & $22: 59$ & $12: 03$ & 0.12 & 47040 & $2.55 .10^{-6}$ & 0.785 & $6.50 .10^{-6}$ \\
\hline 16.1 .2013 & $0: 06$ & $12: 39$ & 0.12 & 45180 & $2.66 .10^{-6}$ & 0.785 & $6.76 .10^{-6}$ \\
\hline $\begin{array}{c}19.9 .2012 \\
20.9 .2012\end{array}$ & $19: 21$ & $15: 05$ & 1.25 & 71040 & $1.76 .10^{-5}$ & 0.785 & $4.48 .10^{-5}$ \\
\hline \begin{tabular}{c}
21.7 .2012 \\
\hline 16.5 .2012
\end{tabular} & $0: 03$ & $11: 02$ & 2.31 & 39540 & $5.84 .10^{-5}$ & 0.785 & $1.49 .10^{-4}$ \\
\hline $\begin{array}{c}17.5 .2012 \\
16.12 .2011\end{array}$ & $10: 29$ & $1: 03$ & 0.3 & 52440 & $5.72 .10^{-6}$ & 0.785 & $1.46 .10^{-5}$ \\
\hline 17.12 .2011 & $17: 08$ & $2: 37$ & 0.72 & 34140 & $2.11 .10^{-5}$ & 0.785 & $5.37 .10^{-5}$ \\
\hline 17.12 .2011 & $6: 16$ & $15: 32$ & 1.16 & 33360 & $3.47 .10^{-5}$ & 0.785 & $8.86 .10^{-5}$ \\
\hline
\end{tabular}


Table 2: Calculated coefficient of filtration in infiltration shaft B - Košice according to ČSN 759010

\begin{tabular}{|c|c|c|c|c|c|c|c|}
\hline Date & $\begin{array}{c}\text { Time } \\
\text { from }\end{array}$ & $\begin{array}{c}\text { Time } \\
\text { to }\end{array}$ & $\begin{array}{c}\text { Volume } \\
\left.\mathbf{m}^{3}\right]\end{array}$ & $\begin{array}{c}\text { Time } \\
{[\mathbf{s}]}\end{array}$ & $\begin{array}{c}\mathbf{Q}_{\mathbf{P}} \\
{\left[\mathbf{m}^{3} \cdot \mathbf{s}^{-1}\right]}\end{array}$ & $\begin{array}{c}\mathbf{A}_{\mathbf{P}} \\
{\left[\mathbf{m}^{2}\right]}\end{array}$ & $\begin{array}{c}\mathbf{k}_{\mathbf{f}} \\
{\left[\mathbf{m . s}^{-1}\right]}\end{array}$ \\
\hline 22.2 .2014 & $1: 18$ & $9: 59$ & 0.38 & 31260 & $1.22 .10^{-5}$ & 0.785 & $3.10 .10^{-5}$ \\
\hline $\begin{array}{c}9.2 .2014 \\
10.2 .2014\end{array}$ & $23: 04$ & $6: 53$ & 1.14 & 28140 & $4.05 .10^{-5}$ & 0.785 & $1.03 .10^{-4}$ \\
\hline 20.1 .2014 & $3: 00$ & $14: 17$ & 1.49 & 40620 & $3.67 .10^{-5}$ & 0.785 & $9.35 .10^{-5}$ \\
\hline $\begin{array}{c}5.11 .2013 \\
6.11 .2013\end{array}$ & $13: 36$ & $1: 00$ & 8.61 & 41040 & $2.10 .10^{-4}$ & 0.785 & $5.35 .10^{-4}$ \\
\hline $\begin{array}{c}9.11 .2013 \\
10.11 .2013\end{array}$ & $20: 02$ & $5: 08$ & 4.08 & 32760 & $1.25 .10^{-4}$ & 0.785 & $3.17 .10^{-4}$ \\
\hline 19.3 .2013 & $2: 03$ & $11: 18$ & 1.87 & 33300 & $5.61 .10^{-5}$ & 0.785 & $1.43 .10^{-4}$ \\
\hline 29.3 .2013 & $7: 40$ & $22: 55$ & 0.85 & 54900 & $1.54 .10^{-5}$ & 0.785 & $3.95 .10^{-5}$ \\
\hline $\begin{array}{l}6.2 .2013 \\
7.2 .2013\end{array}$ & $17: 54$ & $3: 11$ & 1.32 & 33420 & $3.95 .10^{-5}$ & 0.785 & $1.01 .10^{-4}$ \\
\hline 7.2 .2013 & $5: 17$ & $16: 57$ & 0.6 & 42000 & $1.43 .10^{-5}$ & 0.785 & $3.64 .10^{-5}$ \\
\hline $\begin{array}{l}14.1 .2013 \\
15.1 .2013\end{array}$ & $22: 59$ & $12: 03$ & 1.55 & 47040 & $3.20 .10^{-5}$ & 0.785 & $8.39 .10^{-5}$ \\
\hline 16.1 .2013 & $0: 06$ & $12: 39$ & 2.48 & 45180 & $5.49 .10^{-5}$ & 0.785 & $1.40 .10^{-4}$ \\
\hline 21.1 .2013 & $0: 23$ & $11: 59$ & 0.84 & 41760 & $2.01 .10^{-5}$ & 0.785 & $5.12 .10^{-5}$ \\
\hline $\begin{array}{l}21.1 .2013 \\
22.1 .2013\end{array}$ & $14: 09$ & $0: 28$ & 1.03 & 37140 & $2.77 .10^{-5}$ & 0.785 & $7.07 .10^{-5}$ \\
\hline $\begin{array}{l}19.9 .2012 \\
20.9 .2012\end{array}$ & $19: 21$ & $15: 05$ & 7.34 & 71040 & $1.03 .10^{-4}$ & 0.785 & $2.63 .10^{-4}$ \\
\hline \begin{tabular}{c}
21.7 .2012 \\
\hline 16.5 .2012
\end{tabular} & $0: 03$ & $11: 02$ & 4.93 & 39540 & $1.24 .10^{-4}$ & 0.785 & $3.18 .10^{-4}$ \\
\hline 17.5 .2012 & $10: 29$ & $1: 03$ & 1.61 & 52440 & $3.07 .10^{-5}$ & 28.26 & $7.82 .10^{-5}$ \\
\hline
\end{tabular}

Table 3: Calculated coefficient of filtration in Prešov according to ČSN 759010

\begin{tabular}{|c|c|c|c|c|c|c|c|}
\hline Date & $\begin{array}{c}\text { Time } \\
\text { from }\end{array}$ & $\begin{array}{c}\text { Time } \\
\text { to }\end{array}$ & $\begin{array}{c}\text { Volume } \\
{\left[\mathbf{m}^{3}\right]}\end{array}$ & $\begin{array}{c}\text { Time } \\
{[\mathbf{s}]}\end{array}$ & $\begin{array}{c}\mathbf{Q}_{\mathbf{P}} \\
{\left[\mathbf{m}^{3} \mathbf{s}^{-1}\right]}\end{array}$ & $\begin{array}{c}\mathbf{A}_{\mathbf{P}} \\
{\left[\mathbf{m}^{2}\right]}\end{array}$ & $\begin{array}{c}\mathbf{k}_{\mathbf{f}} \\
{\left[\mathbf{m . s}^{-1}\right]}\end{array}$ \\
\hline $\begin{array}{c}2.4 .2013 \\
4.4 .2013\end{array}$ & $22: 52$ & $3: 46$ & 1.72 & 104040 & $1.65 .10^{-5}$ & 46.08 & $7.18 .10^{-7}$ \\
\hline 2.2 .2013 & $12: 18$ & $21: 50$ & 0.45 & 34320 & $1.31 .10^{-5}$ & 46.08 & $5.69 .10^{-7}$ \\
\hline $\begin{array}{c}15.1 .2013 \\
16.1 .2013\end{array}$ & $11: 10$ & $14: 51$ & 3.15 & 99660 & $3.16 .10^{-5}$ & 46.08 & $1.37 .10^{-6}$ \\
\hline $\begin{array}{c}17.12 .2012 \\
18.12 .2012\end{array}$ & $8: 05$ & $10: 57$ & 0.56 & 96720 & $5.79 .10^{-6}$ & 46.08 & $2.51 .10^{-7}$ \\
\hline 1.11 .2012 & $10: 40$ & $23: 02$ & 0.12 & 44520 & $2.71 .10^{-6}$ & 46.08 & $1.18 .10^{-7}$ \\
\hline $\begin{array}{l}19.9 .2012 \\
20.9 .2012\end{array}$ & $19: 49$ & $15: 51$ & 3.07 & 72120 & $4.26 .10^{-6}$ & 46.08 & $1.85 .10^{-6}$ \\
\hline
\end{tabular}


The average values of coefficient of filtration from calculation according to ČSN 759010 were compared with the results from laboratory analysis, where the coefficient of filtration was state based on the curve of granularity are presented in Tab.4.

Table 4: Comparison of the results of coefficients of filtration

\begin{tabular}{|c|c|c|c|}
\hline & $\begin{array}{c}\text { Infiltration shaft A } \\
\text { Košice } \\
\boldsymbol{k}_{\mathbf{f}} \\
{\left[\mathbf{m . s}^{-1}\right]}\end{array}$ & $\begin{array}{c}\text { Infiltration shaft A } \\
\text { Košice } \\
\mathbf{k}_{\mathbf{f}} \\
{\left[\mathbf{m . s}^{-1}\right]}\end{array}$ & $\begin{array}{c}\text { Infiltration gallery } \\
\text { Prešov } \\
\mathbf{k}_{\mathbf{f}} \\
{\left[\mathbf{m}^{-\mathbf{1}}\right]}\end{array}$ \\
\hline $\begin{array}{c}\text { Average value } \\
\text { calculated according } \\
\text { to ČSN 759010 }\end{array}$ & $5,63 \mathrm{E}-05$ & $1,50 \mathrm{E}-04$ & $8,13 \mathrm{E}-07$ \\
\hline $\begin{array}{c}\text { Laboratory analysis } \\
\text { according to the curve } \\
\text { of granularity }\end{array}$ & $1,58 \mathrm{E}-03$ & $1,89 \mathrm{E}-04$ & $4,84 \mathrm{E}-07$ \\
\hline $\begin{array}{c}\text { Average coefficient } \\
\text { of filtration }\end{array}$ & $\mathbf{8 , 1 8 E - 0 4}$ & $\mathbf{1 , 7 0 E - 0 4}$ & $\mathbf{6 , 4 9 E - 0 7}$ \\
\hline
\end{tabular}

The value of the coefficient of filtration changes with time of devices' exploitation as a result of the silting of infiltration equipment and soil filter. It brings to the reduction of rainwater flow intensity through the porous of soil medium, causing also the reduction of infiltration process efficiency. The use of rainwater infiltration devices is especially recommended in the areas which are characterized by the value of soil coefficient of filtration - coefficient of hydraulic conductivity $k_{\mathrm{f}}$ in the range of $1.00 \mathrm{E}-03$ to $1.00 \mathrm{E}-06 \mathrm{~m} / \mathrm{s}$.

The results of the assessment prove that in the area in the campus of Technical University of Košice is suitable for using the infiltration facilities, while the coefficients of filtration have values $8.18 \mathrm{E}-04$ and $1.70 \mathrm{E}-04$ and they are in the range of $1.00 \mathrm{E}-03$ to $1.00 \mathrm{E}-06 \mathrm{~m} / \mathrm{s}$.

The coefficient of filtration in Šarišské Lúky in Prešov has value of 6.49E-07 which is not in the range of $1.00 \mathrm{E}-03$ to $1.00 \mathrm{E}-06 \mathrm{~m} / \mathrm{s}$ and is not suitable for using the infiltration facilities.

\section{Conclusion}

Concerning the proportion of evaporation, infiltration and runoff, rainwater infiltration can contribute essential benefits to harmonization of the natural water balance, and also positively influence soil, weather, fauna and vegetation conditions. Hence, infiltration management can not only significantly reduce the peak runoff into sewers, but also allow the size of the sewage pipes required to handle the waste stream to be reduced, which is important when aging systems have to be rebuilt. In addition, the construction of retention and infiltration systems is usually more economical than the construction of a technical rainwater utilization system, and the related construction work generally does not limit the use of space above ground, since the systems can be also installed underground [8].

Infiltration control represents one of the best methods of rainwater management which may effectively reduce the load on the sewerage network. 
Rainwater management should be considered as a sustainable strategy for reconstruction of rural and urban settlements from the aspects of environmental management and social criteria $[9,10]$. There are many possibilities which can reduce the risk of flooding and regulate the quantity and quality of ground water [11]. Most of these possibilities are proposed only by theoretical calculation based on norms. Our aim is to compare theoretical calculations with results from practice.

The results prove that the study area in Košice is suitable for infiltration of rainwater, while the study area in Prešov has is not suitable for infiltration of rainwater. The infiltration gallery in Prešov was improperly designed on the basis of bad input data.

The conclusion is that the functionality of the infiltration facility mainly depends on the project design and on the proper input data, mainly from hydrogeological survey.

Best management practices reflect the natural process of infiltration that can be found in nonurban basins. Infiltration control belongs among the best management practices that are able to effectively reduce the overloading of sewerage systems by rainwater drainage. If local conditions allow, part of the urban runoff must be controlled by infiltration.

The new challenge for management of rainwater and groundwater requires a fundamental change in the way we think about this issue. Rainwater should be regarded from the point of view of alternative, sustainable strategies and as rehabilitation of rural and urban settlements in the context of environmental, economic and social criteria.

\section{Acknowledgements}

The Centre was supported by the Slovak Research and Development Agency under the contract No. SUSPP-0007-09.

\section{References}

[1] Krejčí, V. et al. (2002). Darinage of urbanized areas - conceptual approach (in Czech). Brno: NOEL 2000 s.r.o.

[2] Hlavínek P. et al. (20070. Rainwater management in urban areas (in Czech). Brno.

[3] General Information for Infiltration Practices. (2008). Iowa Stormwater Management (ISM) Manual.

[4] Zeleňáková, M., Rejdovjanová, G. (2010). Drainage possibilities and its alternations (in Slovak). Proceedings of IX LAWA conference Košice: Elsewa.

[5] ATV-DVWK A 138E. (2005). Planning, Construction and Operation of Facilities for the Percolation of Precipitation Water.

[6] Ahmidat, M. K. M., Káposztásová, D., Markovič, G., Vranayová, Z. (2014). The effect of roof material on rain water quality parameters in conditions of Slovak Republic In: Advances in Environmental Sciences, Development and Chemistry: Proceedings of the 2014 Conference on Water Resources, Hydraulics and Hydrology, Greece, Santorini: Europment, p. 275-280.

[7] Markovič, G., Zeleňáková, M., Káposztásová, D., Hudáková, G. (2014). Rainwater infiltration in the urban areas. In: Environmental Impact 2. Southampton: WIT press, Vol. 181, p. 313-320. 
[8] Markovič, G. Káposztásová, D., Vranayová, Z. (2014). The analysis of the possible use of harvested rainwater in real conditions at the university campus of Kosice In: Recent Advances in Environmental Science and Geoscience: Proceeding of the 2014 Conference on Environmental Science and Geoscience, Italy, Venice: Europment, p. 82-88.

[9] Zeleňáková M., Bálintová M., Foraiová K. (2009). Rain water management for the purposes of sustainable development. In: Zeszyty naukowe Politechniki Rzeszowskiej: Budownictwo i Inzynieria Srodowiska. Vol. 266/54, p. 119-128.

[10] Ondrejka Harbulakova, V., Homzova, E. (2013). Možnosti zachytávania a využívania zrážkových vôd z povrchového odtoku, 2013. In: Životné prostredie - Problémy a možnosti riešenia: ovzdušie - voda - pôda: zborník z 3. ročníka odbornej konferencie s medzinárodnou účast'ou: Nový Smokovec, 8.-10.4.2013. - Košice: Elsewa, 2013 S. 135-142.

[11] Ondrejka Harbulakova, V. (2014). Floodwalls and levees as a measures of flood protection. In: Zborník recenzovaných vedeckých prác ÚEI 2014. TU Košice, p. 64-70. 